\title{
COMMENTARY
}

\section{Metallophytes in Latin America: a remarkable biological and genetic resource scarcely known and studied in the region}

\author{
Metalófitas en América Latina: un recurso biológico y genético \\ único poco conocido y estudiado en la región \\ ROSANNA GINOCCHIO ${ }^{1} \&$ ALAN J.M. BAKER ${ }^{2}$ \\ ${ }^{1}$ Centro de Investigación Minera y Metalúrgica, Av. Parque Antonio Rabat 6500, \\ Santiago, Chile; e-mail: rginocc@cimm.cl \\ ${ }^{2}$ School of Botany, The University of Melbourne, VIC 3010, Australia, \\ e-mail: ajmb@unimelb.edu.au
}

\begin{abstract}
In Latin America, metallic ores are abundant and diverse. However, few metal-tolerant and metal hyperaccumulator plants have been reported in the region in comparison with other areas of the world. This may be largely explained by the scarcity of scientific studies of the native vegetation growing on natural mineralized or metal-contaminated areas and the unfrequent use of biogeochemical prospecting techniques by the local mining industry, rather than the proven absence of these plants. Latin America is, however, an area where metal-tolerant and hyperaccumulator plants (metallophytes) should be found, not only because of the wealth of ore deposits and associated metal polluted areas, but also due to its high and unique plant diversity. If plant formations developed over natural mineral outcrops are not evaluated before ore extraction, we can loose key metal tolerant species and/or genotypes (ecotypes) forever which may be useful for the mitigation of environmental problems generated by the mining industry itself (e.g., phytoextraction, phytostabilization, and phytomining).
\end{abstract}

Key words: hyperaccumulators, metal-tolerant plants, biodiversity, metal ores, biogeochemistry.

\section{RESUMEN}

América Latina posee una gran abundancia y diversidad de yacimientos minerales metálicos. Sin embargo, se han descrito pocas especies tolerantes e hiperacumuladoras de metales en comparación con otras regiones del mundo. Esto podría deberse tanto a la escasez de estudios científicos sobre la vegetación nativa que se ha desarrollado sobre mineralizaciones superficiales o en suelos enriquecidos antrópicamente con metales como a la falta de métodos biogeoquímicos para la prospección de minerales, más bien que a la ausencia real de este tipo de especies vegetales en la región. Latinoamérica es, sin embargo, un área con gran potencial para la presencia de este tipo de especies vegetales, no solo por el gran número de mineralizaciones y áreas contaminadas con metales presentes, sino que por su variada y única diversidad vegetal. Si las comunidades vegetales presentes sobre mineralizaciones naturales no se estudian antes de que se lleven a cabo procesos de extracción de minerales, podrían perderse para siempre especies y/o genotipos (ecotipos) claves para ser usados en la mitigación de problemas ambientales relacionados con el propio sector minero (e.g., fitoextracción, fitoestabilización y fitominería).

Palabras clave: hiperacumuladoras, plantas tolerantes a metales pesados, biodiversidad vegetal, yacimientos minerales, metalófitas, biogeoquímica.

\section{INTRODUCTION}

Heavy metals such as cobalt, copper, iron, manganese, molybdenum, nickel, and zinc are essential micronutrients for living organisms, but at elevated concentrations they are toxic to higher plants (Lambers et al. 1998). There is a group of plants, however, called metallophytes that dominate on mineralized areas, either natural (e.g., serpentine or ultramafic soils) or anthropogenic ones (e.g., metal smelter hinterlands, tailings dumps), that have developed through time biological mechanisms allowing them to resist metal concentrations that are toxic to most plants (Reeves \& Baker 2000). Metal tolerance in higher plants has been traditionally assessed through standardized laboratory tests by determining 
the effect of metal ions on root elongation (e.g., Baker \& Walker 1989, Lambers et al. 1998). Using this methodology, numerous studies have identified and quantified metal tolerance for copper, cadmium, iron, manganese, nickel, lead, and zinc in several higher plants (e.g., Allen \& Sheppard 1971, Hogan et al. 1977, Baker \& Brooks 1989, Macnair et al. 1993, Ginocchio et al. 2002).

In terms of the inorganic composition, most metallophytes are either indifferent to the metal-rich environment or minimally affected by the uptake of a slightly higher than normal concentration of the elements in the enriched soil (Reeves \& Baker 2000). However, some metallophytes can accumulate very high concentrations of metallic or metalloid elements in their aerial tissues, to levels far in excess of normal physiological requirements and far in excess of the levels found in most plant species, even those tolerant of metalliferous soils (Table 1). These plants are known as hyperaccummulators (Baker \& Brooks 1989, Baker et al. 1999, Reeves \& Baker 2000). They have evolved efficient metal-uptake mechanisms and effective methods for metal sequestration in internal tissues (Fernández \& Henríquez 1991, Ernst et al. 1992, Briat \& Lebrun 1999). Indeed, some of these plants can not complete their life cycles when grown on normal soils.

Metallophytes may have very restricted geographical distributions and thus can correspond to rare species (Reeves 1992). They are often endemic to few small areas of

TABLE 1

Criteria for hyperaccumulator plants

Criterios para plantas hiperacumuladoras

\begin{tabular}{lc}
\hline Metal & $\begin{array}{c}\text { Shoot } \\
\text { concentration } \\
(\%, \text { dry matter })\end{array}$ \\
\hline Arsenic & $>0.1$ \\
Cadmium & $>0.01$ \\
Cobalt & $>0.1$ \\
Copper & $>0.1$ \\
Lead & $>0.1$ \\
Manganese & $>1.0$ \\
Nickel & $>0.1$ \\
Selenium & $>0.1$ \\
Zinc & $>1.0$ \\
\hline
\end{tabular}

metalliferous soils; some are known from only a single site or have been collected in only few occasions (e.g., Baker \& Brooks 1988, Malaisse et al. 1994, Léteinturier et al. 2001). Some are adapted variants (ecotypes) of common species (pseudometallophytes), such as Deschampsia caespitosa (Cox \& Hutchinson 1980, Bush \& Barret 1993), Holcus lanatus (Baker 1984), and Mimulus gutattus (Allen \& Sheppard 1971, Macnair et al. 1993), and can be found widely over metal-rich environments. Others, however, are species strictly restricted to their particular metallogenic provinces, such as some Becium species, that only grow on isolated natural copper outcrops in the Democratic Republic of Congo (formerly Zaire), central Africa (Brooks et al. 1992a).

Hyperaccumulator plants represent a low percentage of all angiosperms (less than 0.2 $\%)$, but they are widely distributed in different genera and families (Baker et al. 1999, Table $2)$. Therefore, they are rare in the Plant Kingdom. The phenomenon has thus evolved several times in widely different plant groups under the same environmental stresses. Their metal-specific adaptations and large diversity in terms of species, families and life-forms, grant metallophytes a special place in issues related to biodiversity and genetic resources conservation. Although the European taxa are well known, tropical and sub-tropical metallophyte taxonomy and ecology lie far behind despite the ever-increasing mining activity taking place in these latitudes.

\section{TABLE 2}

Numbers of metal hyperaccumulator plants in the world (based on records from Reeves \& Baker 2000)

Número de plantas hiperacumuladas de metales en el mundo (basado en registros de Reeves \& Baker 2000)

Metal Number of taxa Number of families

Arsenic

Cadmium

Cobalt

Copper

Lead

Manganese

7

Nickel

Selenium

Zinc

20 


\section{METALLOPHYTES AND THE} METAL MINING INDUSTRY

The historical interaction between metallophytes and the mining industry has been diverse and quite contrasting. First, the restricted distribution of metallophytes to metalliferous soils has brought about a negative interaction with the mining sector, since these plants grow where the metal ores occur and are extracted from the ground. Although the mining sector is not necessarily the most important influence on plant diversity in a particular region, mining does almost always have an impact on biodiversity and, in some cases, the effects can be huge and irreversible, even in industrialized countries with developed environmental regulations (MMSD 2002). According to the Australian National Parks and Wildlife Service mining is still responsible for $1.1 \%$ of presumed extinctions of endangered plant species (Leigh \& Briggs 1992) and the World Resources Institute suggests that mining, roads and infrastructure threatens $38 \%$ of forest frontiers (WWF International \& IUCN 1999). Indeed, opencast mine operantions results in total clearance of vegetation and topsoil over large surfaces, and although new and good-managed operations make provisions for rehabilitation, such impacts are more far-reaching than those of the other sectors (e.g., grazing and agriculture), as they do not necessarily protect local metallophyte germoplasms for rehabilitation. For instance, iron extraction from the Amazonian forest in the Grande Carajas Project, Brazil, has already affected about $90,000 \mathrm{~km}^{2}$ of forest (WWF International \& IUCN 1999). Opencast copper exploitation in the copper belt of the Congo, central Africa, has in the last decade brought about the extinction of an important number of site-specific metallophytes, endemic to only a single site or a very restricted area of distribution (Léteinturier et al. 2001). The same loss is occurring in areas of ferronickel exploitation in Venezuela ('Loma de Hierro'; Barreto \& Casale 2002 ${ }^{1}$ ) and Dominican Republic (Puerto Plata District; Peguero \& Clase $2002^{2}$ ) where endemic plants

\footnotetext{
${ }^{1}$ BARRETO L \& I CASALE (2002) Caracterización de las plantas asociadas a los suelos serpentiníticos de Loma de Hierro, Venezuela. Octavo Congreso Latinoamericano de Botánica, Cartagena de Indias, Colombia, Libro de resúmenes: 357.

${ }^{2}$ PEGUERO B \& T CLASE (2002) Flora y vegetación serpentinícola de la franja costera Maimón-Guzmancito, Puerto Plata, República Dominicana. Octavo Congreso Latinoamericano de Botánica, Cartagena de Indias, Colombia, Libro de resúmenes: 358 .
}

growing on serpentine soils have been completely removed by opencast operations.

Regulations for environmental protection have dramatically improved since 1980-1990 in some Latin American countries, such as Chile, Peru, and Bolivia, but they are still diverse in terms of biodiversity protection and rehabilitation requirements of mined sites (MMSD América del Sur 2002). The best practices for rehabilitation in the region have usually been the introduction of exotic species that have had many deleterous effects on native plants and ecosystems or the introduction of exotic species that have had better livelihood benefits, such as woody trees for fuel, timber, or food for cattle. In some cases, introduction of native species that are able to survive in the mined environment has happened, but these programs have mainly considered the specific identity of plants and not their metal tolerance and accumulation status.

Second, metallophytes endemic to areas of well-defined soil composition have been used historically as geobotanical indicators for mineral exploration. For instance, some of these plants have extensively been used in Europe and central Africa as metal bioindicators as they can be used to delineate metalliferous substrates when prospecting for metal ores (Brooks 1998). Third, further uses for metallophytes by the mining industry have been promoted in the most recent drive towards sustainable development and responsible mine site closure in Europe and North America (Whiting et al. 2002). On the one hand, endemic metallophytes can be used in the revegetation and restoration of former mined sites (phytostabilization), and on the other, they can be used in the clean-up of toxic metals from soils (phytoextraction) or in the phytomining of low grade ore that cannot be processed economically by other techniques (Baker et al. 1999, Tordoff et al. 2000).

The deposition of metal-rich wastes in terrestrial environments by the metal mining industry (e.g. tailings dumps and sterile piles), has generated new habitats for potential microevolution and colonization of metal adapted variants of common species and for metalophytes colonization (e.g., Allen \& Sheppard 1971, Baker 1984, Bush \& Barret 1993, Ginocchio et al. 2002). Abandoned and naturally recolonized old mine sites can therefore be seen not only as a liability but also a resource base of unique genetic materials. The study of these plants and their colonization behaviour and evolution observable on former mine sites has improved closure and 
rehabititation strategies in some mined areas of developed countries (e.g., Gunn 1995).

\section{METALLOPHYTES IN LATIN AMERICA}

Although the Region is very rich in ore deposits, few metal-tolerant and metalhyperaccumulator plants have been reported in comparison with other areas of the world. Brooks (1993) noted that in comparison with North America, Oceania, Asia, Europe and Africa, the biogeochemical data available for mine sites in Latin America was very few. However, this may be better explained by the scarcity of both scientific studies on native vegetation growing on natural mineralized or metal-contaminated areas and biogeochemical prospecting with plants, rather than the proven absence of these plants in the Region. Information on metallophytes in Latin America has been derived from two main sources: scientific research performed by botanists and plant ecologists and geobotanical surveys performed by geologists and mining engineers.
Scientific research on metallophytes has been scarce in the region; 172 plant species have been described in the literature as either metal tolerant (30 species) or hyperaccumulators (142 species; Figure 1 and Table 3 ), a low number when compared to the high diversity of plant species present in the Region (Cincotta et al. 2000). Most of these plants are nickel tolerants and hyperaccumulators $(89 \%)$ as most of the studies pertain to serpentine areas of Brazil, Cuba, Dominican Republic, and Venezuela, followed by copper (5\%) and arsenic (3\%, Figure 1 and Table 3). Investigations over ultramafic rocks in Argentina and Paraguay (Reeves \& Brooks 2000) and heavily metal-polluted soils near a copper smelter in central Chile (Ginocchio $\left.1997,1999^{3}, 2000\right)$ have also been performed but they have not revealed further metal tolerant plants. It is clear then that from all the rich plant biodiversity present in Latin America only few species have been reported as metallophytes and investigations have been concentrated on ultramafic soils of few countries. It is also important to note that local scientists have not been involved in these

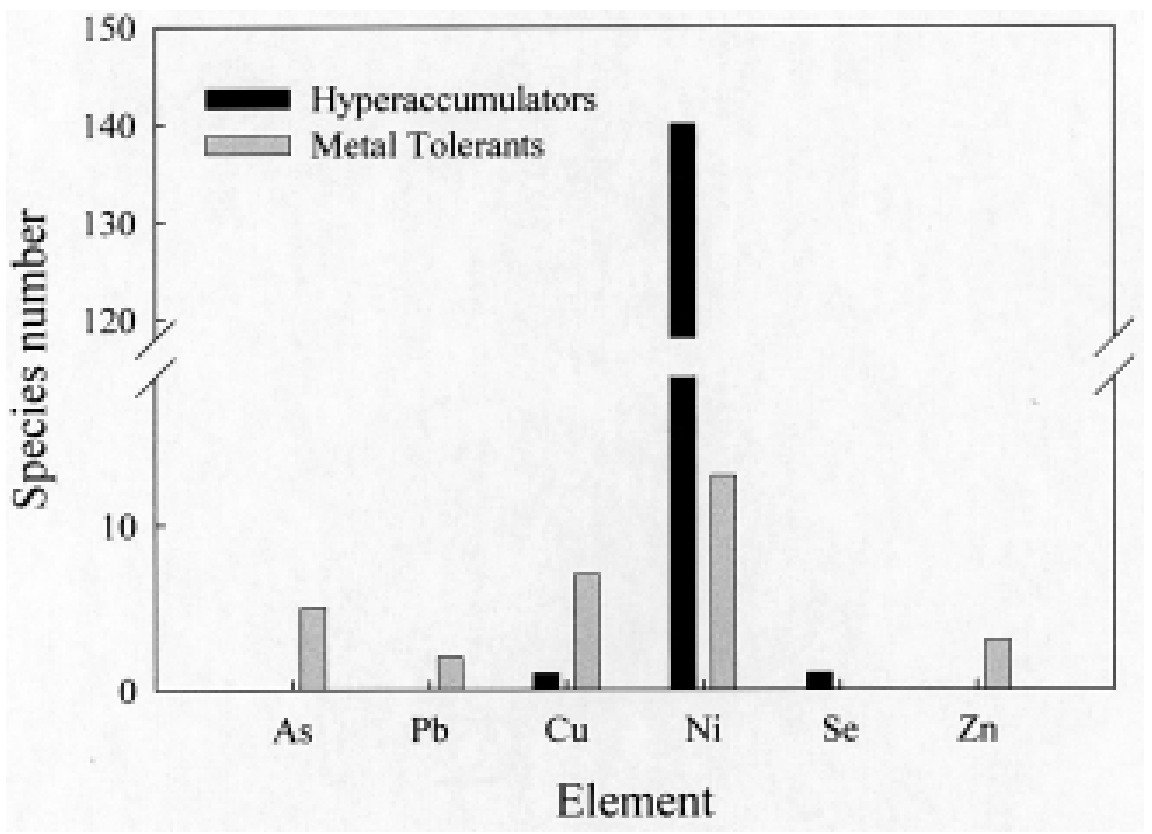

Fig. 1: Total number of metallophytes per trace element described in Latin America.

Número de metalófitas para distintos elementos traza descritas en América Latina.

\footnotetext{
${ }^{3}$ GINOCCHIO R (1999) Copper tolerance testing on plant species growing near a copper smelter in central Chile: 1156-1157. Proceedings of the Fifth International Conference on the Biogeochemistry of Trace Elements, Vienna, Austria.
} 
TABLE 3

Metallophytes described in Latin America from the literature: (MT) metal tolerant; (H) hyperaccumulator Metalófitas descritas en la literatura para América Latina: (MT) tolerante a metal; (H) hiperacumuladora

\begin{tabular}{|c|c|c|c|c|}
\hline Country & Metal & Plant type & Species & References \\
\hline Brazil & $\mathrm{Ni}$ & $\begin{array}{l}\mathrm{H} \\
\mathrm{H} \\
\mathrm{H} \\
\mathrm{H} \\
\mathrm{H} \\
\mathrm{H} \\
\mathrm{H} \\
\mathrm{H} \\
\mathrm{H} \\
\mathrm{H} \\
\mathrm{H}\end{array}$ & $\begin{array}{l}\text { Adiantum } \mathrm{sp} . \\
\text { Chromolaena } \mathrm{sp} . \\
\text { Cnidolcolus } \mathrm{sp} . \\
\text { Esterhazya } \mathrm{sp} . \\
\text { Heliotropium } \mathrm{sp} \text {. } \\
\text { Justicia lanstyakii } \mathrm{sp} . \\
\text { Laphostachys villosa } \mathrm{sp} \text {. } \\
\text { Mitracarpus } \mathrm{sp} . \\
\text { Ruellia geminiflora } \mathrm{sp} . \\
\text { Turnera subnuda } \mathrm{sp} . \\
\text { Vellozia } \mathrm{sp}\end{array}$ & Brooks et al. $(1990,1992 b)$ \\
\hline Chile & $\mathrm{Cu}$ & $\begin{array}{r}\text { MT } \\
\text { MT } \\
\text { MT } \\
\text { MT } \\
\text { MT? } \\
\text { MT }\end{array}$ & $\begin{array}{l}\text { Mimulus luteus var. variegatus } \\
\text { Cenchrus echinatus } \\
\text { Erygeron berterianum } \\
\text { Mullinum spinosum } \\
\text { Nolana divaricata } \\
\text { Dactylium sp. }\end{array}$ & $\begin{array}{l}\text { Ginocchio et al. (2002) } \\
\text { Bech et al. (2001a)* } \\
\text { Ruelle (1995) } \\
\text { Ortiz et al. (2002) }\end{array}$ \\
\hline Cuba & $\mathrm{Cu}$ & $\begin{array}{l}\mathrm{H} \\
\mathrm{H} \\
\mathrm{H} \\
\mathrm{H} \\
\mathrm{H} \\
\mathrm{H} \\
\mathrm{H} \\
\mathrm{H} \\
\mathrm{H} \\
\mathrm{H} \\
\mathrm{H} \\
\mathrm{H} \\
\mathrm{H} \\
\mathrm{H} \\
\mathrm{H} \\
\mathrm{H} \\
\mathrm{H} \\
\mathrm{H} \\
\mathrm{H} \\
\mathrm{H} \\
\mathrm{H} \\
\mathrm{H} \\
\mathrm{H} \\
\mathrm{H} \\
\mathrm{H} \\
\mathrm{H}\end{array}$ & $\begin{array}{l}\text { Ariadne (2 spp) } \\
\text { Bonania }(3 \mathrm{spp}) \\
\text { Buxus }(17 \mathrm{spp}) \\
\text { Chionantus domingensis } \\
\text { Euphorbia }(3 \mathrm{spp}) \\
\text { Garcinia }(4 \mathrm{spp}) \\
\text { Gochnatia recurva } \\
\text { Gochnatia crassifolia } \\
\text { Gymnanthes recurva } \\
\text { Koanophyllon grandiceps } \\
\text { Koanophyllon prinoides } \\
\text { Leucocroton }(28 \mathrm{spp}) \\
\text { Mosiera }(4 \mathrm{spp}) \\
\text { Ouratea }(2 \mathrm{spp}) \\
\text { Pentacalia }(10 \mathrm{spp}) \\
\text { Phidiasia lindavii } \\
\text { Phyllomelia coronata } \\
\text { Psidium }(2 \mathrm{sppp}) \\
\text { Psychotria }(5 \mathrm{spp}) \\
\text { Rondeletia }(2 \mathrm{spp}) \\
\text { Sapium erythrosperum } \\
\text { Savia }(3 \text { spp) } \\
\text { Senecio }(6 \mathrm{spp}) \\
\text { Shafera platyphilla } \\
\text { Tetralix (5 spp) } \\
\text { Phyllanthus williamioides }\end{array}$ & Reeves et al. (1996, 1999) \\
\hline Ecuador & $\begin{array}{l}\mathrm{Pb} \\
\mathrm{As}\end{array}$ & $\begin{array}{l}\text { MT } \\
\text { MT } \\
\text { MT } \\
\text { MT? } \\
\text { MT? } \\
\text { MT? } \\
\text { MT? }\end{array}$ & $\begin{array}{l}\text { Baccharis amdatensis } \\
\text { Rumex crispus } \\
\text { Pennisetum clandestinum } \\
\text { Chenopodium ambrosioides } \\
\text { Pennisetum clandestinum } \\
\text { Holcus lanatus } \\
\text { Pennisetum clandestinum }\end{array}$ & Bech et al. $(2001 b)^{* * *}$ \\
\hline Peru & $\mathrm{Cu}$ & $\begin{array}{r}\mathrm{H} \\
\mathrm{H} \\
\mathrm{H} \\
\mathrm{MT} ?\end{array}$ & $\begin{array}{l}\text { Bidens cinapiifolia } \\
\text { Paspalum racemosum } \\
\text { Paspalum tuberosum } \\
\text { Bidens cinapiifolia }\end{array}$ & $\begin{array}{l}\text { Bech et al. (1997) } \\
\text { Bech et al. }(2001 \mathrm{a})^{*}\end{array}$ \\
\hline $\begin{array}{l}\text { Dominican } \\
\text { Republic }\end{array}$ & $\mathrm{Ni}$ & $\begin{array}{r}\mathrm{H} ? \\
\mathrm{MT} ?\end{array}$ & $\begin{array}{l}\text { Senecio plumbeus } \\
10 \text { serpentinitic endemic species }\end{array}$ & Peguero \& Clase (2002) \\
\hline Venezuela & $\begin{array}{l}\mathrm{Se} \\
\mathrm{Ni}\end{array}$ & $\begin{array}{r}\mathrm{H} \\
\mathrm{H} \\
\mathrm{H} \\
\mathrm{H} \\
\mathrm{MT} ? \\
\mathrm{MT} ? \\
\text { MT? }\end{array}$ & $\begin{array}{l}\text { Lecythis ollaria } \\
\text { Waltheria americana } \\
\text { Oyedea } \mathrm{sp} . \\
\text { Croton sp. } \\
\text { Lepidaploa remotiflora } \\
\text { Borreria verticillata } \\
\text { Wedelia calycina }\end{array}$ & $\begin{array}{l}\text { Aronow \& Kerdel-Vegas (1965) } \\
\text { Barreto \& Casale (2002) }\end{array}$ \\
\hline
\end{tabular}

*BECH J, Ch POSCHENRIEDER, J BARCELÓ \& A LANSAC (2001a) Plants from mine spoils in the South American area as potential source of germplasm for phytoremediation technologies. Proceedings of the Phytoremediation Conference, ISEB, UFZ Centre for Environmental Research, Leipzig, Germany

**BECH J, Ch POSCHENRIEDER, J BARCELÓ \& A LANSAC (2001b) Heavy metal and arsenic accumulation in selected plants species around a silver mine in Ecuador: 393. Proceedings of the Sixth International Conference on the Biogeochemistry of Trace Elements, Guelph, Canada 
issues until recent years (e.g., Ginocchio et al. 1997, 2000, Barreto \& Casale 2002 ${ }^{1}$, Ortiz et al. 2002), perhaps due to the lack of interests or knowledge by Latin American scientists, local governments and mining companies on basic and applied research related to this particular group of plants.

Large-scale mining in Latin America has used traditional methods of exploration for minerals based on geology (e.g., rock coloration), radiometrics, photogeology, thermal analysis, geochemistry and satellite imaging. Geobotanical methods of mineral exploration by the way of detection of subsurface mineralization by an interpretation of its vegetative cover or 'indicator plants' (Brooks 1998), have been rather scarce. It is not suprising therefore that geobotanical surveys of the region are rarely reported in the literature (see Table 4). However, geobotanical surveys may have been performed by some mining companies during the course of mineral exploration but the results may be hidden in confidential reports and thus are not available for the public domain. One of the few geobotanical surveys published in the region are those of Viladevall et al. (19944) in Bolivia and Fernández-Turiel et al. $\left(1994^{5}\right)$ in Argentina. Viladevall et al. (19944) found that Baccharis incarum and Fabiana densa are good to be used as metal indicator plants in geobotanical surveys for $\mathrm{Au}, \mathrm{As}, \mathrm{Sb}$ and other metals/metalloids in the altiplanic areas of Bolivia, since their leaves are reliable indicators of metal contents in the sub-soil.
Although these plants cannot be classified as hyperaccumulator plants since they achieve a maximum of $101 \mathrm{ppb}$ of $\mathrm{Au}$ and $540 \mathrm{ppm}$ of $\mathrm{Sb}$ in their leaves, they may be considered as metallophytes. Fernández-Turiel et al. $\left(1994^{5}\right)$ found that Prosopis alba and Larrea divaricata growing near an old smelter in the Sierra Pampeanas in Argentina had 2 to 6 times more $\mathrm{Sr}, \mathrm{Cd}, \mathrm{Bi}, \mathrm{Zn}, \mathrm{Ni}, \mathrm{Li}$, and $\mathrm{Cu}$ than the same plants growing on unpolluted soils. They reported that all the shrubs studied had the same pattern of metal accumulation in aboveground structures, with the exception of Prosopis alba and P. nigra which accumulated more $\mathrm{Zn}$ than the other plants growing in the same soils ( $700 \mathrm{mg} \mathrm{Zn}$ per $\mathrm{kg}$ of ash versus 200 $\mathrm{mg} \mathrm{Zn}$ per $\mathrm{kg}$ of ash).

It is interesting to note that the species described by Viladevall et al. (19944) and Fernández-Turiel et al. (19945) have wide distributional ranges. For example, $B$. incarum is a dominant shrub in the Altiplanic zone of Bolivia that covers $130,000 \mathrm{~km}^{2}$ between 3,350 and $4,350 \mathrm{~m}$ of altitude but it is also present in Chile. Furthermore, $F$. dens $a$ is present in Bolivia and Chile while $P$. alba and $L$. divaricata are found in Argentina and Chile. Therefore, we may speculate that metal-tolerant ecotypes may have evolved on metal-rich soils in these other countries where they have not been described as indicators or metallophytes.

Identification of metallophytes in Latin America seems to be increasing in the last decade, but numbers should further increase as the region has high potential for harbouring

TABLE 4

Metal indicator plants in Latin America from geobotanical surveys

Plantas indicadoras de metal en América Latina según catastros geobotánicos

\begin{tabular}{|c|c|c|c|}
\hline Country & Indicator metal & Species & Reference \\
\hline Argentina & $\begin{array}{l}\mathrm{Zn} \\
\mathrm{Cu}, \mathrm{Zn}, \mathrm{Ni}, \mathrm{Sr}, \mathrm{Li}, \mathrm{Cd}, \mathrm{Bi}\end{array}$ & $\begin{array}{l}\text { Prosopia alba } \\
\text { Prosopis nigra } \\
\text { Prosopis alba } \\
\text { Larrea divaricata }\end{array}$ & Fernández-Turiel et al. (1994) \\
\hline Bolivia & $\mathrm{Au}, \mathrm{As}, \mathrm{Sb}$ & $\begin{array}{l}\text { Baccharis incarum } \\
\text { Fabiana densa }\end{array}$ & Viladevall et al. (1994) \\
\hline
\end{tabular}

4 VILADEVALL M, RS SANTIVÁÑEZ, J PONCE, H ALARCÓN, E VALENZUELA, J SAAVEDRA, E PELLITERO, A MURCIEGO, J BABKINE \& Y DUSAUSOY (1994) El análisis de las tholas como método de exploración de menas de antimonio-oro en el altiplano Boliviano: 1264-1267. Actas del Séptimo Congreso Geológico Chileno, Volumen II, Concepción, Chile.

\footnotetext{
${ }^{5}$ FERNÁNDEZ-TURIEL JL, JN ROSSI, PA PEÑALOZA, ME MEDINA, J SAAVEDRA, F DURÁN, JP LÓPEZ, X QUEROL, A LÓPEZ-SOLER \& AJ TOSELLI (1994) Implicaciones ambientales del estudio biogeoquímico de la Sierra de Famatina, La Rioja, Argentina: 613-617. Actas del Séptimo Congreso Geológico Chileno, Concepción, Chile.
} 
metal-tolerant and hyperaccumulator plants. This is not only due to the large number of ore deposits and metal-enriched areas (such those found near abandoned tailings dumps and metal smelters) distributed throughout the region, but also due to its high and unique plant diversity. Latin America has major centers of plant diversity in comparison with other areas of the world. Indeed, eight of the twenty-five biodiversity hotspot areas so far defined in the world for their high biodiversity are located in Latin America (Fig. 2, Cincotta et al. 2000). Furthermore, the Mediterranean-type climate region and the winter rainfall deserts of Chile have recently been classified under the highest

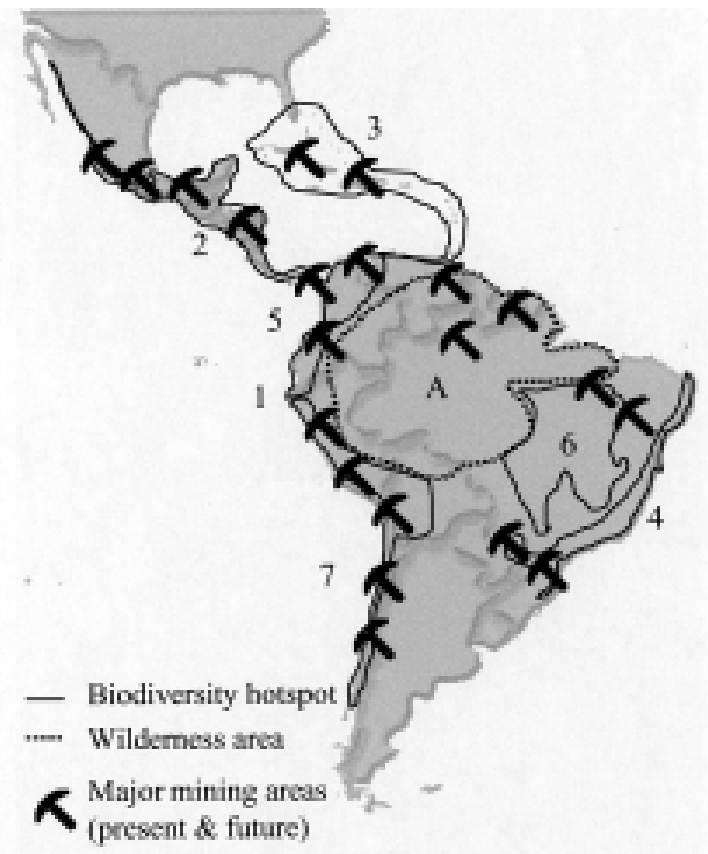

Fig. 2: Hotspots for biodiversity and mining in Latin America (from Cincotta et al. 2000 and WWF International \& IUCN 1999, respectively). Hotspots for biodiversity: (1) Tropical Andes, (2) Central America, (3) Caribbean, (4) Atlantic Forest Region, (5) Western Ecuador Chocó-Darién, (6) Brazilian Cerrado, and (7) Central Chile. Major tropical wilderness areas: (A) Upper Amazonia and Guyana.

Áreas de concentración de biodiversidad y de minería en América Latina (fuente Cincotta et al. 2000 and WWF International \& IUCN 1999, respectivamente). Áreas de concentración de biodiversidad: (1) Andes Tropicales, (2) América Central, (3) Caribe, (4) Región Forestal Atlántica, (5) Ecuador Occidental Chocó-Darién, (6) Cerrado Brasileño, y (7) Chile central. Áreas tropicales silvestres: (A) Amazonía superior y Guyana. priority at the regional scale for biodiversity conservation of ecoregions of Latin America (Arroyo et al. 1999) on the basis of biological distinctiveness and conservation status. However, all this high diversity is still poorly evaluated, studied, and protected, including that of potential and known metallophytes.

\section{CONSIDERATIONS FOR CONSERVATION OF METALLOPHYTES IN THE REGION}

Metal mining in Latin America has not only been important in the last decades. New and strong investments in ore exploration and exploitation have been made both within the private and government sectors, assuring the future of the metal mining industry. Indeed, the Guyanan and Andean regions of Latin America and the Pacific Rim are two of the five mining hotspots identified in the world (WWF International \& IUCN 1999). These regions are also coincident with hotspots for biodiversity (Fig. 2) where vegetation has already been affected by mining operations or by heavy pressure from metal mining, due particularly to badly planned and managed mining operations (e.g., WWF International \& IUCN 1999, Castro \& Sánchez 2003). For example, in terms of vulnerability to metal mining activities, it is important to note that many of the Chilean vascular plants (particularly perennial herbs and shrubs) have a very limited distributional range (Arroyo \& Cavieres 1997, Villagrán \& Hinojosa 1997). Thus they are highly vulnerable to extinction if present and future mining is not adequately regulated. The same situation may prevail for metallophytes with restricted distributional ranges.

The lack of environmental regulations for the mine sector in most Latin American countries until recent decades resulted in severe threats to local vegetation in general and metallophytes in particular. Although the situation has changed due to the establishment of environmental laws and regulations in some countries of the region, such as Peru, Bolivia, and Chile (MMSD América del Sur 2002), others have followed a tendency to review or relax the environmental standards governing mining to encourage investment, trade liberalization, technological change, crossborder merges and acquisitions, increased influence from large corporations and investor pressure (WWF International \& IUCN 1999). Latin America has attracted the majority of the world's investments in mining, and therefore new laws and regulations alone may be not 
enough to prevent present and future threats to metallophytes that may be discovered in the region, due mainly to habitat loss. Despite these problems, some progress by Latin American governments, mining industries and international actions to protect biodiversity such as the Convention on Biological Diversity is being made at policy, regulatory and technical levels.

Therefore, a major effort is required by local scientists, government agencies and mining companies to recognize and study metallophytes that may exist in Latin America. Extensive geobotanical exploration is needed not only on mineralized areas but also on abandoned tailings dumps or other metalenriched areas. The risk is that they may be eliminated by mining activities before they have ever been identified.

\section{CONCLUSIONS}

There is a lack of knowledge on metallophytes throughout Latin America. However, there is a great potential for this particular group of plants in the region as plant biodiversity is high and unique and metal ores occur in abundance. Vigorous efforts must therefore be made in Latin America to locate metallophytes in their natural habitats and to afford them adequate protection.

Metal mining has posed serious threats to plant diversity in the region, including known and to-be recognized metallophytes, and it will continue so if no special consideration is taken with this special group of plants. Local plant extinctions can be caused by any sectorial activity, but metallophytes are likely to go extinc as a result of mining activity alone, as they grow on or near mining deposits. The obliteration of this special group of plants will result in the loss of a potentially valuable resource that can be used by the mine sector in best-practices for closure and rehabititation of mined sites, as they constitute a remarkable biological resource of great potential in the phytoremediation of metal-enriched soils and metal-rich wastes.

\section{ACKNOWLEDGEMENTS}

The authors wish to extend their thanks to Ignacia Toro and to acknowledge the support of Rio Tinto Plc., the Ministry of Mines of Chile, FONDECYT grant 1000750, FONDEF grant D00I1042, DIPUC, CODELCO-Chile, and CODELCO-El Teniente.

\section{LITERATURE CITED}

ADAMEK P, P DEVRIWS \& JC ENRÍQUEZ (1998) Regional assessment. Mining Environmental Management 6: 16-19.

ALLEN WR \& PM SHEPPARD (1971) Copper tolerance in some Californian populations of the monkey flower, Mimulus guttatus. Proceedings of the Royal Society of London B 177: 177-196.

ARONOW L \& F KERDEL-VEGAS (1965) Selenocystathionine, a pharmacologically active factor in the seeds of Lecythis ollaria. Nature 205: 1185 1186.

ARROYO MTK \& L CAVIERES (1997) The Mediterranean-type climate flora of central Chile. What do we know and how we can assure its protection. Noticiero de Biología 5: 48-55.

ARROYO MTK, R ROZZI, J SIMONETTI, P MARQUET \& M SALABERRY (1999) Central Chile. In: Mittermeier RA, N Myers \& CG Mittermeier (eds) Hotspots: Earth's biologically richest and most endangered terrestrial ecosystems: 161-171. CEMEX, Mexico, Distrito Federal.

BAKER AJM (1984) Environmentally-induced cadmium tolerance in the grass Holcus lanatus L. Chemosphere 13: 585-598.

BAKER AJM \& RR BROOKS (1988) Botanical exploration for minerals in the humid tropics. Journal of Biogeography 15: 221-229.

BAKER AJM \& RR BROOKS (1989) Terrestrial higher plants which hyperaccumulate metallic elements. A review of their distribution, ecology and phytochemistry. Biorecovery 1: 81-126.

BAKER AJM \& PL WALKER (1989) Physiological responses of plants to heavy metals and the quantification of tolerance and toxicity. Chemical Speciation and Bioavailability 1: 7-17.

BAKER AJM, SP McGRATH, RD REEVES \& JAC SMITH (1999) Metal hyperaccumulator plants: a review of the ecology and physiology of a biological resource for phytoremediation of metal-polluted soils. In: Terry $\mathrm{N}$ \& GS Bañuelos (eds) Phytoremediation of contaminated soil and water: 85-107. Lewis Publishers, Boca Raton, Florida, USA.

BECH J, Ch POSCHENRIEDER, M LLUGANY, J BARCELÓ, P TUME, FJ TOBIAS, JL BARRANZUELA \& ER VÁSQUEZ (1997) Arsenic and heavy metal contamination of soil and vegetation around a copper mine in Northern Peru. Science of the Total Environment 203: 83-91.

BRIAT J-F \& M LEBRUN (1999) Plant responses to metal toxicity. Comptes Rendus Académie des Sciences 322: 43-54.

BROOKS RR (1993) Geobotanical and biogeochemical methods for detecting mineralization and pollution from heavy metals in Oceania, Asia, and the Americas. In: Markert B (ed) Plants as biomonitors. Indicators for heavy metals in the terrestrial environment: 127-153. VCH, Weinheim, Germany.

BROOKS RR (1998) Geobotany and hyperaccumulators. In: Brooks RR (ed) Plants that hyperaccumulate heavy metals. Their role in phytoremediation, microbiology, archaeology, mineral exploration and phytomining: 55-94. CAB International, Oxon., United Kingdom.

BROOKS RR, RD REEVES, AJM BAKER, JA RIZZO \& $H$ DÍAZ-FERREIRA (1990) The Brazilian Serpentine Plant Expedition (BRASPEX), 1988. National Geographic Research and Exploration 6: 205-219. 
BROOKS RR, AJM BAKER \& F MALAISSE (1992a) Copper flowers: the unique flora of the copper hills of Zaïre. National Geographic Research and Exploration 8: 338-351.

BROOKS RR, RD REEVES \& AJM BAKER (1992b) The serpentine vegetation of the Goiás State, Brazil. In: Baker AJM, J Proctor \& RD Reeves (eds) The vegetation of ultramafic (serpentine) soils: 67-81. Intercept Ltd., Andover, United Kingdom.

BUSH EJ \& SCH BARRET (1993) Genetics of mine invasions by Deschampsia caespitosa (Poaceae). Canadian Journal of Botany 71: 1336-1348.

CARDOSO M \& E CEDILLO (1990) Geologicmetallogenic evolution of the Peruvian Andes. In: Amstutz GC, M Cardoso, E Cedillo, L Fontbote \& J Frutos (eds) Stratabound ore deposits in the Andes: 37-60. Springer-Verlag, Berlin, Germany.

CASTRO SH \& M SÁNCHEZ (2003) Environmental viewpoint on small-scale copper, gold and silver mining in Chile. Journal of Cleaner Production 11: 207-213.

CINCOTTA RP, J WISNEWSKI \& R ENGELMAN (2000) Human population in the biodiversity hotspots. Nature 404: 990-992.

COX RM \& TC HUTCHINSON (1980) Multiple metal tolerances in the grass Deschampsia caespitosa (L.) Beauv. From the Sudbury smelting area. New Phytologist 84: 631-647.

COWLING RM, PW RUNDEL, BB LAMONT, MK ARROYO \& M ARIANOUTSOU (1996) Plant diversity in mediterranean-climate regions. Trends in Ecology and Evolution 11: 362-366.

ERNST WHO, JAC VERKLEIJ \& H SCHAT (1992) Metal tolerance in plants. Acta Botanica Neerlandica 41: 229-248

FERNÁNDEZ JC \& FS HENRÍQUEZ (1991) Biochemical, physiological, and structural effects of excess copper in plants. Botanical Review 57: 246-273.

FORERO C \& A FERNÁNDEZ (1998) Mining development in Colombia. Mining Environmental Management 6: 24-25.

GINOCCHIO R (1997) Aplicabilidad de los modelos de distribución espacio-temporales de la vegetación en ecosistemas terrestres sujetos a procesos de contaminación ambiental. Ph.D. Thesis, P. Universidad Católica de Chile, Santiago, Chile. 209 pp.

GINOCCHIO R (1998) Chile: restoration challenges. Mining Environmental Management 6: 7- 9.

GINOCCHIO R (2000) Effects of a copper smelter on a grassland community in the Puchuncaví Valley, Chile. Chemosphere 41: 15-23.

GINOCCHIO R, I TORO \& D SCHNEPF (2002) Copper tolerance in populations of Mimulus luteus var. variegatus exposed and non exposed to copper pollution. Geochemistry: Exploration, Environment, Analysis 2: 151-156.

JUN JM (1995) restoration and recovery o fan industrial region. Progress in restoring the smelter-damaged landscape near Sudbury, Canada. Springer-Verlag, New York, New York, USA. 358 pp.

HOGAN GD, GM COURTIN \& WE RAUSER (1977) Copper tolerance in clones of Agrostis gigantea from a mine waste site. Canadian Journal of Botany 55: 1043-1050.

LAMBERS H, FS III CHAPIN \& TL PONS (1998) Plant physiological ecology. Springer-Verlag, New York, New York, USA. 540 pp.

LEIGH JD \& JH BRIGGS (1992) Threatened Australian plants: overview and case studies. Australian
National Parks and Wildlife Service, Canberra, Australia. $120 \mathrm{pp}$.

LÉTEINTURIER B, AJM BAKER, L BOCK, J MATERA \& F MALAISSE (2001) Copper and vegetation at the Kansanshi Hill (Zambia) copper mine. Belgian Journal of Botany 134: 41-50.

MACNAIR MR, SE SMITH \& QJ CUMBES (1993) Heritability and distribution of variation in degree of copper tolerance in Mimulus guttatus at Copperopolis, California. Heredity 71: 445-455.

MALAISSE F, RR BROOKS \& AJM BAKER (1994) Diversity of vegetation communities in relation to soil heavy-metal content at the Shinkolobwe copper/cobalt/uranium mineralization, Upper Shaba, Zaire. Belgian Journal of Botany 127: 3-16.

MMSD AMÉRICA DEL SUR (2002). Minería, minerales y desarrollo sustentable en América del Sur. Coeditado por Centro de Investigación y Planificación del Medio Ambiente (CIPMA) y Centro Internacional de Investigaciones para el Desarrollo (IDRC) - Iniciativa de Investigación sobre Políticas Mineras (IIPM). Internacional Institute for Environment and Sustainable Development (IIED) \& World Business Council for Sustainable Development (WBCSD), London, United Kingdom. $623 \mathrm{pp}$.

MMSD (2002) Mining, minerals and sustainable development. Draft Report. Internacional Institute for Environment and Sustainable Development (IIED) \& World Business Council for Sustainable Development (WBCSD), London, United Kingdom. $556 \mathrm{pp}$.

ORTIZ C, J LI KAO \& S ORELLANA (2002) Acumulación y tolerancia a $\mathrm{Cu}++$ en una gramínea silvestre: potencial de uso en fitorremediación. Biological Research 35: R-93.

REEVES RD (1992) Hyperaccumulation of nickel by serpentine plants. In: Baker AJM, J Proctor \& RD Reeves (eds) The vegetation of ultramafic (serpentine) soils: 253-277. Intercept Ltd., Andover, United Kingdom.

REEVES RD, AJM BAKER, A BORHIDI \& $R$ BERAZAÍN (1996) Nickel-accumulating plants from the ancient serpentine soils of Cuba. New Phytologist 133: 217-224

REEVES RD, AJM BAKER, A BORHIDI \& $R$ BERAZAÍN (1999) Nickel hyperaccumulation in the serpentine flora of Cuba. Annals of Botany 83: 29-38.

REEVES RD \& AJM BAKER (2000) Metal-accumulating plants. In: Raskin I \& BD Ensley (eds) Phytoremediation of toxic metals: using plants to clean up the environment: 193-229. John Wiley and Sons Inc., New York, New York, USA.

RUELLE S (1995) Etude d'impact de la pollution métallique sur le site de Paposo (II Région, Chili). Travail de fin d'études 'Ingénieur Agronome, Faculté Universitaire des Sciences Agronomiques de Gembloux, Gembloux, Belgium. 127 pp.

SOLBRIG OT (1984) Mining. Mountain Research and Development 4: 175-179.

TORDOFF GM, AJM BAKER \& AJ WILLIS (2000) Current approaches to the revegetation and reclamation of metalliferous mine wastes. Chemosphere 41: 219-228.

VILLAGRÁN C \& LF HINOJOSA (1997) Historia de los bosques de Sudamérica II: fitogeografía. Revista Chilena de Historia Natural 70: 241-267.

WHITING SN, RD REEVES \& AJM BAKER (2002) Conserving biodiversity: mining, metallophytes and 
land reclamation: conservation of biodiversity. Mining Environmental Management 10: 11-16.

WWF INTERNATIONAL \& IUCN (1999) Metals from the forests. Mining and forest degradation. Special issue of the newsletter Arborvitae (January 1999): 1-40.

Associate Editor: Matías Medina

Received June 12, 2003; accepted October 1, 2003
ZAMARSKY V, H CONN \& M TABAK (1972) Estudio geoquímico de los productos de intemperismo de las rocas ultrabásicas (serpentinitas) en la provincia de Valdivia, Chile. Instituto de Investigación Geológica, Universidad de Chile, Santiago, Chile. 67 pp. 